\title{
Detection and molecular characterization of piroplasms species from naturally infected dogs in southeast Brazil
}

Detecção e caracterização molecular de piroplasmas em cães naturalmente infectados no Sudeste do Brasil

Tatiana Didonet Lemos ${ }^{1 *}$; Aloysio de Mello Figueiredo Cerqueira ${ }^{2}$; Helena Keiko Toma ${ }^{3}$; Adrianna Vieira da Silva ${ }^{4}$; Rafael Gomes Bartolomeu Corrêa $a^{4}$; Giane Regina Paludo5; Carlos Luiz Massard ${ }^{6}$; Nádia Regina Pereira Almosny ${ }^{1}$

${ }^{1}$ Departamento de Patologia e Clínica Veterinária, Universidade Federal Fluminense - UFF, Niterói, RJ, Brasil

${ }^{2}$ Departamento de Microbiologia e Parasitologia, Universidade Federal Fluminense - UFF, Niterói, RJ, Brasil

${ }^{3}$ Laboratório de Diagnóstico Molecular e Hematologia, Faculdade de Farmácia, Universidade Federal do Rio de Janeiro - UFRJ, Rio de Janeiro, RJ Brasil

${ }^{4}$ VetLab Análises Clínicas Veterinárias, Rio de Janeiro, RJ Brasil

${ }^{5}$ Faculdade de Agronomia e Medicina Veterinária, Universidade de Brasília - UnB, Brasília, DF, Brasil

${ }^{6}$ Departamento de Parasitologia Animal, Universidade Federal Rural do Rio de Janeiro - UFRRJ, Rio de Janeiro, RJ Brasil

Received May 21, 2012

Accepted June 8, 2012

\begin{abstract}
Rangelia vitalii is a protozoon described from dogs in the south and southeast regions of Brazil. It is phylogenetically related to Babesia spp. that infects dogs, but data on this enigmatic parasite is still limited. The aim of this work was to detect piroplasm species in dogs in the state of Rio de Janeiro, Brazil, by $18 \mathrm{~S}$ rRNA gene-based PCR assay, restriction fragment length polymorphism (RFLP) and sequence analyses. Of 103 dogs examined, seven (6.8\%) were positive for Babesia spp. by PCR. The amplified products were digested by restriction enzymes to differentiate the Babesia species, and one sample was identified as Babesia vogeli. The pattern observed for the other six amplification products did not match with pattern described for large Babesia infecting dogs. Sequencing analysis confirmed these six samples as $R$. vitalii, with high homologies (99-100\%) with a sequence from south Brazil. This study confirms the presence of Babesia vogeli and Rangelia vitalii circulate in domestic dogs in Teresópolis, Rio de Janeiro, Brazil.
\end{abstract}

Keywords: Babesia vogeli, Rangelia vitalii, piroplasms, dogs, PCR.

\section{Resumo}

Rangelia vitalii é um protozoário que infecta cáes e foi descrito nas regiôes Sul e Sudeste do Brasil. $R$. vitalii é filogeneticamente próxima à Babesia spp., mas dados deste misterioso parasito ainda são escassos. O objetivo deste trabalho foi detectar a presença de piroplasmas em cães naturalmente infectados no estado do Rio de Janeiro, através da amplificação do gene $18 \mathrm{~S}$ rRNA pela PCR, clivagem com enzimas de restrição (RFLP) e caracterização genética através do sequenciamento. De 103 cáes, sete (6,8\%) foram positivos para Babesia spp. pela PCR. Os produtos amplificados foram digeridos por enzimas de restrição para a diferenciação das espécies de Babesia e uma amostra foi identificada como Babesia vogeli. $\mathrm{O}$ padrão de amplificação observado nas outras seis amostras não correspondeu ao padrão descrito para babesias que infectam cães. O sequenciamento das seis amostras confirmou ser uma espécie geneticamente idêntica a $R$. vitalii apresentando grande homologia (99-100\%) com a sequência do sul do Brasil. Este estudo confirma a presença de Babesia vogeli e Rangelia vitalii infectando cães em Teresópolis, Rio de Janeiro, Brasil.

Palavras-chave: Babesia vogeli, Rangelia vitalii, piroplasmas, cáes, PCR.

\section{Introduction}

Canine babesiosis is a parasitosis caused by the intraerythrocytic protozoa of the genus Babesia (LEVINE, 1973). Traditionally, Babesia classification in dogs is performed microscopically

${ }^{*}$ Corresponding author: Tatiana Didonet Lemos

Departamento de Patologia e Clínica Veterinária,

Universidade Federal Fluminense - UFF, Rua Vital Brasil, 64,

Santa Rosa, Niterói, RJ, Brasil

e-mail: tatididonet@gmail.com based on the parasite morphology in the erythrocytes. Large Babesia are usually referred to as "B. canis", whereas small Babesia as "B. gibsoni" (SOLANO-GALEGO et al., 2008). Recent advances in molecular techniques have enabled the detection and identification of piroplasmid species that infect dogs. Babesia canis is divided into three genetically distinct species: $B$. canis, B. vogeli and B. rossi (UILENBERG, 2006). A new species of large (as yet unnamed) Babesia has been described infecting 
dogs in North Carolina, USA (BIRKENHEUER et al., 2004; LEHTINEN et al., 2008). Nowadays, other small piroplasms are known to infect dogs including Theileria annae (ZAHLER et al., 2000), B. conradae (CONRAD et al., 1991; KJEMTRUP; CONRAD, 2006), T. annulata (CRIADO et al., 2006), T. equi (CRIADO-FORNELIO et al., 2003) and Theileria sp. (MATJILA et al., 2008).

Rangelia vitalii is an intracellular parasite belonging to the phylum Apicomplexa and order Piroplasmida (LORETTI; BARROS, 2004). This protozoan infects dogs and is supposedly transmitted by ticks and causes a disease that is popularly known as "nambiuvú" (bloody ears) or "plague of blood". This illness has been described only in the south and southeast regions of Brazil (BRAGA, 1935; LORETTI; BARROS, 2004, 2005; DA SILVA et al., 2011). In a recent study conducted in southern Brazil R. vitalii was molecularly characterized (SOARES et al., 2011).

Rangelia vitalii is described as infecting mainly young dogs, but adult dogs can become infected. Dogs that live in both rural and urban areas may be affected. It is believed that the vectors of this agent are ticks of the species Riphicephalus sanguineus and Amblyomma aureolatum (LORETTI; BARROS, 2004, 2005).

The life cycle of $R$. vitalii consists of an erythrocytic stage of development and exoeritrocytic form occurring in the cytoplasm of neutrophils, monocytes and endothelial cells (LORETTI; BARROS, 2005; SOARES et al., 2011). Morphologically, intraerythrocytic forms are very similar to B. vogeli, and pyriform to round shapes can be arranged in pairs on the same erythrocyte. Piroplasms are found in the blood circulation, mainly in the acute phase of infection. Parasites are numerous in histological sections of organs such as liver, spleen, kidneys, lungs and bone marrow. In these organs, the parasites are found in capillary endothelial cells and reticuloendothelial cells (CARINI; MACIEL, 1914; CARINI, 1948; LORETTI; BARROS, 2005).

Recent molecular studies characterized B. vogeli (PASSOS et al., 2005; SÁ et al., 2006), B. gibsoni (TRAPP et al., 2006) and R. vitalii (DA SILVA et al., 2011; SOARES et al., 2011) as the causative agents of canine piroplasmosis in Brazil. Studies on this disease are limited, especially those involving the molecular characterization of these piroplasmids in different regions of Brazil. Therefore, it is important to better characterize the piroplasm species infecting dogs in Brazil in order to improve the diagnosis and treatment of the diseases they cause.

The aim of this study was to detect and characterize piroplasm species in dogs from southeastern Brazil using both parasitological (buffy coat and capillary blood smear examination) and molecular methods (polymerase chain reaction (PCR), restriction fragment length polymorphism (RFLP) and sequence analyses).

\section{Material and Methods}

\section{Samples and optic microscopy}

Blood samples from 103 dogs examined in a private veterinary clinic in Teresópolis, Rio de Janeiro, were used in this experiment. The area (22 $24^{\prime} 44^{\prime \prime} \mathrm{N}$ and $\left.42^{\circ} 57^{\prime} 56^{\prime \prime} \mathrm{W}\right)$ (http://www.apolo11.com) is located in the mountainous region of Rio de Janeiro, has a tropical latitude climate, with an annual average temperature of $20^{\circ} \mathrm{C}$ (http://www.teresopolis.rj.gov.br/). The animals were selected with no preference for breed, age or sex during the period between November 2006 and May 2008.

Blood samples for DNA extraction were collected in tubes containing 10\% ethylenediaminetetraacetic acid anticoagulant. Capillary blood smears were made at the moment of sample collection and were stained by quick-stain procedures (Instant-Prove ${ }^{\odot}$ ) for hemoparasite screening. The featherd edge and the lateral borders of the smears were examinated.

\section{Extraction, amplification, RFLP and DNA sequencing}

DNA extraction was performed with $200 \mu \mathrm{L}$ of total blood, using the Illustra Blood Genomicprep Kit (GE Health Care $\left.{ }^{\circ}\right)$ according to the manufacturer's instructions. From the DNA extracted from each sample, a fragment of the $18 \mathrm{~S}$ rRNA was amplified with primers PIRO A (5-AAT ACC CAA TCC TGA CAC AGG G-3') and PIRO B (5'-TTA AAT ACG AAT GCC CCC AAC- $\left.3{ }^{\prime}\right)$. The program consisted in an initial denaturation step at $94^{\circ} \mathrm{C}$ for 5 minutes, followed by 30 denaturation cycles at $94^{\circ} \mathrm{C}$ for 1 minute, annealing at $55^{\circ} \mathrm{C}$ for 1 minute and extension at $72{ }^{\circ} \mathrm{C}$ for 1 minute. A final extension step at $72{ }^{\circ} \mathrm{C}$ for 5 minutes was used (CARRET et al., 1999).

To define the species of Babesia, the amplification products were digested with the enzymes $\operatorname{Hinf} \mathrm{I}$ (Biolabs ${ }^{\circ}$, New England) and Taq I (Biolabs ${ }^{\circ}$, New England) for 3 hours (CARRET et al., 1999) and then analyzed by $2 \%$ agarose gel electrophoresis.

Only samples that showed different restriction patterns from piroplasm species described in the literature were sequenced from data of two previous amplifications of the 18S rRNA gene, as described by Soares et al. (2011) with modifications. The sequences were aligned using the program Mega version 5 (TAMURA et al., 2011) to generate the unique sequence of each sample. The first PCR was performed with primers Bab 33-57 (5'-GCC AGT AGT CAT ATG CTT GTC TTA A- ${ }^{\prime}$ ) and Bab 432-409 (5'-TTC CTT AGA TGT GGT AGC CGT TTC- $3^{\prime}$ ), which amplify a fragment of $-370 \mathrm{bp}$. The program consisted of an initial denaturation step at $95^{\circ} \mathrm{C}$ for 5 minutes, followed by 40 denaturation cycles at $95^{\circ} \mathrm{C}$ for 40 seconds, annealing at $56{ }^{\circ} \mathrm{C}$ for 40 seconds and extension at $72{ }^{\circ} \mathrm{C}$ for 40 seconds. A final extension step at $72^{\circ} \mathrm{C}$ for 5 minutes was performed. In the second amplification, the primers Bab 143-167 (5'-CCG TGC TAA TTG TAG GGC TAA TAC A- $3^{\prime}$ ) and Bab 858-834 (5'-CCT CTG ACA GTT AAA TAC GAA TGC C- $3^{\prime}$ ) were used, the latter being designed herein to amplify a fragment of $-715 \mathrm{bp}$. The reaction conditions were as follows: an initial denaturation step at $95^{\circ} \mathrm{C}$ for 5 minutes, followed by 40 denaturation cycles at $95^{\circ} \mathrm{C}$ for 1 minute, annealing at $64^{\circ} \mathrm{C}$ for 1 minute and extension at $72{ }^{\circ} \mathrm{C}$ for 1 minute. A final extension step at $72{ }^{\circ} \mathrm{C}$ for 5 minutes was performed. For all amplifications, previously known positive $B$. vogeli samples and negative samples were used as controls.

The amplicons were purified with the commercial PureLink ${ }^{\mathrm{TM}}$ PCR Purification Kit (Invitrogen ${ }^{\circ}$, Carlsbad, CA, USA), according to the manufacturer's instruction. The purified DNA was sequenced by the automated sequencer ABI Prism 3130. 


\section{Phylogenetic analysis}

The sequences obtained by amplifying the gene fragment encoding the $18 \mathrm{~S}$ rRNA, when sequenced with primers BAB 33-57/BAB 432-409 and BAB 143-167/BAB 858-834, were compared with those available in the GenBank through the BLAST program. The genetic similarity tree was constructed using the algorithm Neighbor Joining of the program MEGA version 5 (TAMURA et al., 2011). For phylogenetic comparison, the following $18 \mathrm{~S}$ rRNA gene sequences were included in the alignment: Rangelia vitalii (HQ150006.1), B. motasi (AY260180.1), B. ovata (AY603400.1), B. gibsoni (EU084677.1), B. canis vogeli (AB083374.1), B. canis canis (AY072926.1), B. canis rossi (DQ111760.1), Theileria annae (AF188001.1), B. bigemina (X59607.1), B. caballi (Z15104.1), B. odocoilei (AY237638.1), B. divergens (U07885.1), B. microti (U09833.1), T. equi (Z15105.1), T. parva (L02366.1), T. annulata (EU083801.1), Cytauxzoon felis (GU903911.1) and Plasmodium falciparum (M19172.1).

\section{Results}

\section{Optic microscopy, PCR assay and RFLP}

In the capillary and circulating blood smears, four (3.9\%) of the 103 dogs evaluated showed intraerythrocytic parasites compatible with Babesia spp.
In all samples that were positive by light microscopy (samples 1, 3, 5 and 7) and three others (samples 2, 4 and 6), the $18 \mathrm{~S}$ rRNA gene fragment of Babesia of approximately $400 \mathrm{bp}$ was amplified. All samples that tested positive by PCR (6.8\%) were submitted to RFLP analysis. Using the enzyme Taq I, only sample 1 was cleaved into three fragments of different sizes. With the exception of sample 1, the other six samples were cleaved with the enzyme Hinf I into two fragments of approximately $200 \mathrm{bp}$, which were not separated by electrophoresis due to their similar size (Figure 1). The pattern of cleavage of sample 1 is consistent with the subspecies B. vogeli (CARRET et al., 1999).

Amplifications using the primer pairs BAB 33-57/BAB 432-409 and $\mathrm{BAB} 143-167 / \mathrm{BAB} 858-834$ produced products of -370 and 715 bp, respectively.

\section{DNA sequencing}

Sample 1 (GenBank access number GQ214514.1), when sequenced with primers PIRO A and PIRO B, shared $100 \%$ identity with $B$. vogeli from Venezuela (GenBank access number DQ297390.1), Japan (GenBank access number AB083374.1) and Brazil (GenBank access number AY371196.1).

Samples 2 through 7 , when sequenced with primers BAB 33-57/BAB 432-409 and BAB 143-167/BAB 858-834, were aligned using the program Mega version 5 (TAMURA et al., 2011) to generate the unique sequence of each sample. The final sequences were deposited into GenBank (GenBank access numbers JN880428, JN880429, JN880430, JN880431, JN880432 and JN880433). Sequences 2 through 6 and sequence 7 shared $99 \%$

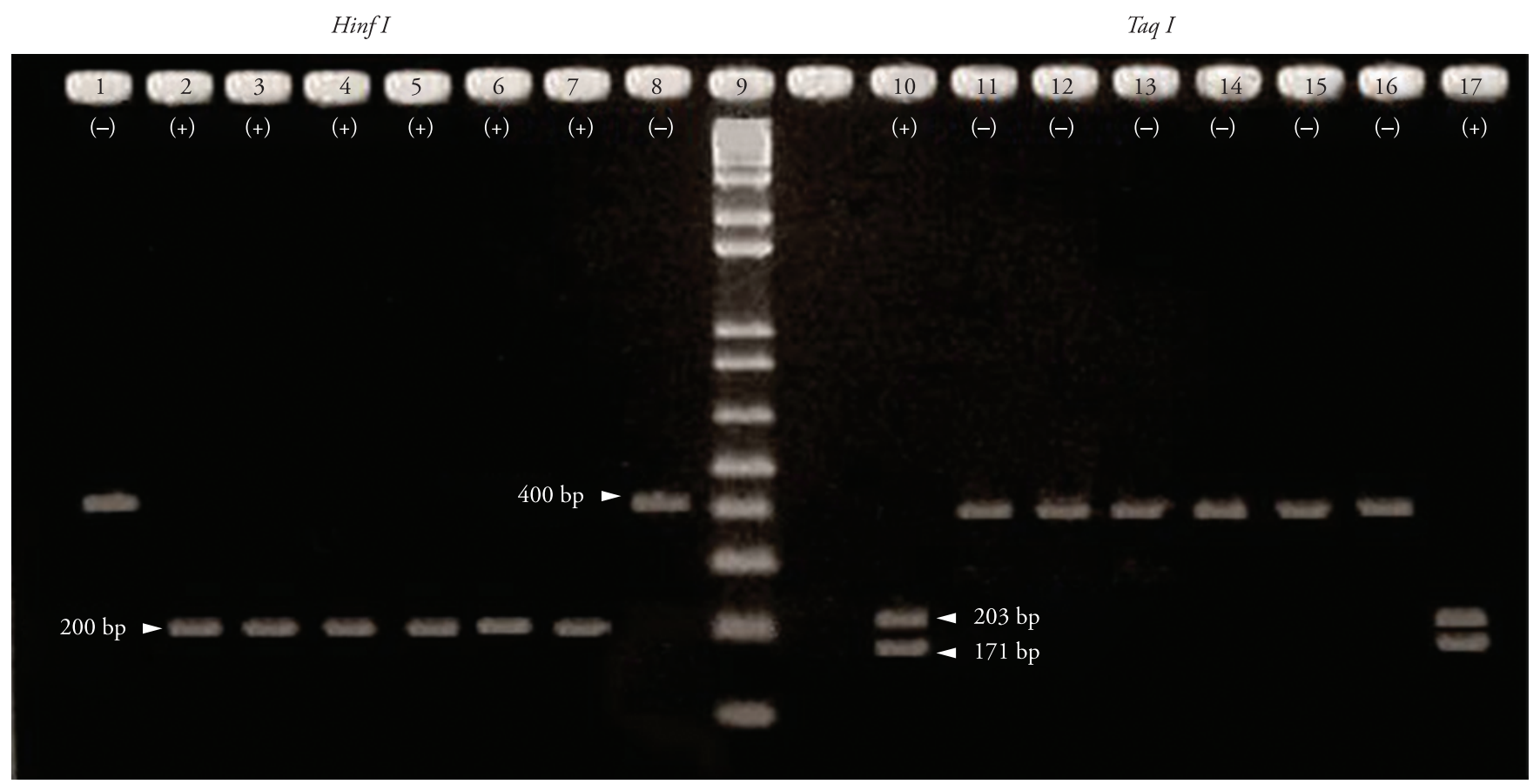

Figure 1. Analysis of PCR-RFLP products (Hinf I and Taq I enzymes) by $2 \%$ agarose gel electrophoresis and ethidium bromide staining. From left to right the lanes contain the following: cleavage with the Hinf I - Babesia vogeli positive sample (lane 1); Babesia spp. positive samples (lanes 2 to 7); B. vogeli positive control (lane 8); cleavage with the Taq I - B. vogeli positive sample (lane 10); Babesia spp. positive samples (lanes 11 to 16); B. vogeli positive control (lane 17); molecular weight marker (lane 9). 


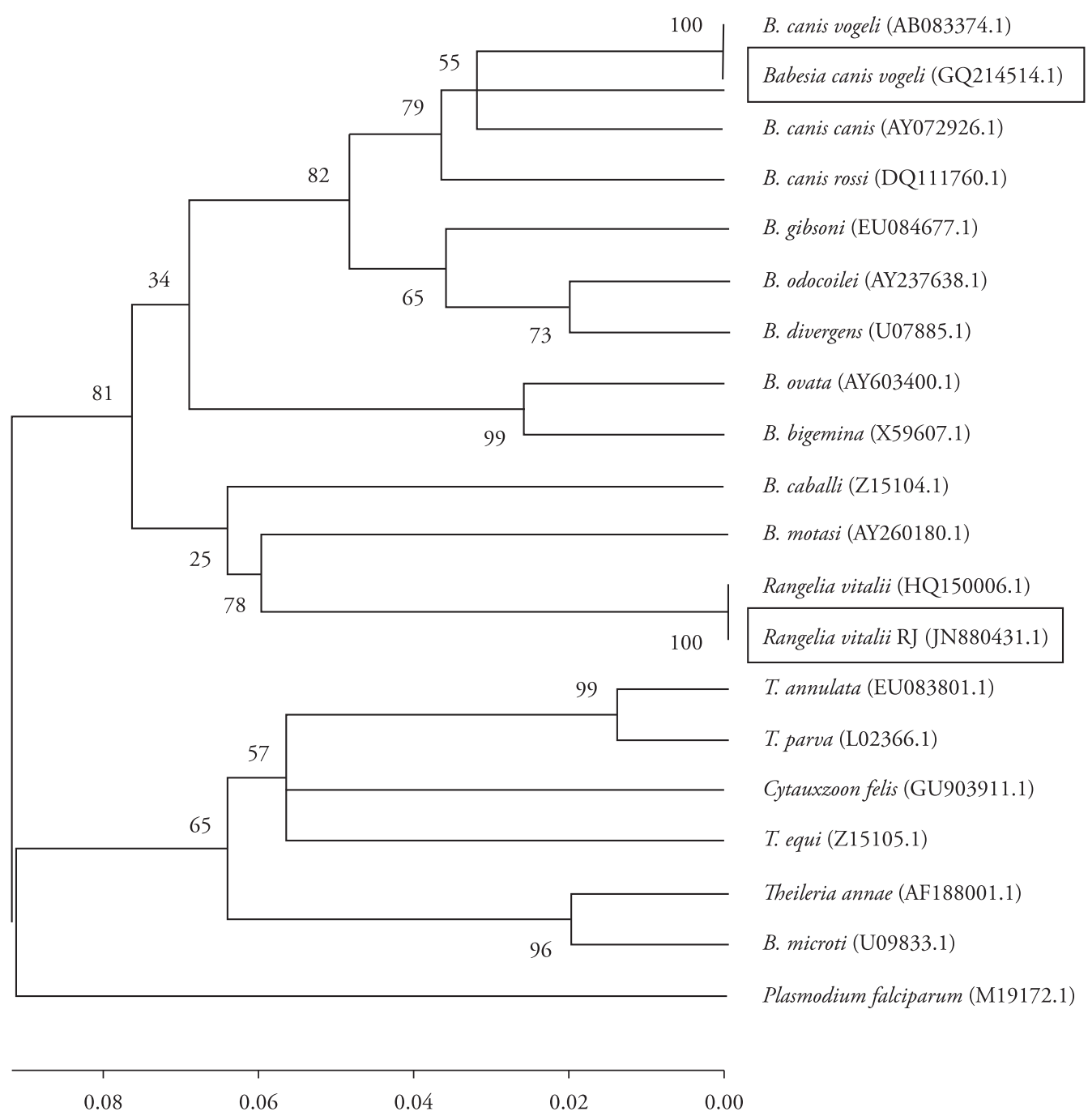

Figure 2. Neighbor-joining phylogenetic tree based on the parcial $18 \mathrm{~S}$ rRNA gene sequences of Babesia vogeli (311 bp) and Rangelia vitalii (796 bp) detected in Rio de Janeiro and similar sequences from GenBank. Bootstrap values were obtained after 1000 resampling. New sequences are marked by rectangles. The outgroup used in this work was Plasmodium falciparum (M19172.1).

and $100 \%$ identity, respectively, with R. vitalii from Santa Maria, Brazil (GenBank access number HQ150006.1).

The phylogenetic tree demonstrated that samples 2 through 7 and the R. vitalii sample from Santa Maria form a new branch of piroplasms (Figure 2), a conclusion that is supported by the high bootstrap value of this phylogenetic analysis.

\section{Discussion}

Molecular studies have revealed a vast genetic diversity of piroplasms infecting dogs (CRIADO-FORNELIO et al., 2003). PCR amplification of $18 \mathrm{~S}$ rRNA partial sequences allows the identification of different Babesia species that were previously indistinguishable due to the similarity in the parasites' morphology (BIRKENHEUER et al., 2004; DUH et al., 2004; MATJILA et al., 2004; SÁ et al., 2006).

Passos et al. (2005) provided the first molecular characterization of $B$. vogeli in Brazil. These authors used blood samples from dogs from the states of São Paulo and Minas Gerais. PCR amplification and sequencing of the $18 \mathrm{~S}$ rRNA showed $100 \%$ similarity between the Brazilian isolates, which were identical to an isolate from Japan (AB083374.1) deposited into GenBank. Sá et al. (2006) performed the first detection of $B$. vogeli in Rio de Janeiro. They used the same protocols for PCR-RFLP as described by Carret et al. (1999).

In our study, PCR-RFLP was found to be a fast and practical method. DNA cleavage of other six samples by the enzyme Hinf I produced fragments that did not match any restriction pattern described in literature, suggesting that these samples were another piroplasmids species (CARRET et al., 1999; SOLANO-GALLEGO et al., 2008).

Recent advances in molecular techniques have enabled the detection and identification of piroplasmid species with high sensitivity and specificity when compared to other diagnostic methods (FÖLDVÁRI et al., 2005). Currently, new piroplasmid species have been reported as infecting dogs, including Theileria annae (ZAHLER et al., 2000), B. conradae (CONRAD et al., 1991; KJEMTRUP et al., 2006), T. annulata (CRIADO et al., 2006), 
T. equi (CRIADO-FORNELIO et al., 2003), Theileria sp. (MATJILA et al., 2008) and a yet undescribed species of large Babesia identified in North Carolina, USA (BIRKENHEUER et al., 2004; LEHTINEN et al., 2008).

Rangelia vitalii, which has been described in the south and southeast regions of Brazil, was shown to be phylogenetically closely related to a Babesia spp. sensu stricto group of piroplasmas that infects dogs (SOARES et al., 2011). This parasite was first described morphologically in the State of São Paulo (PESTANA, $1910 \mathrm{a}, \mathrm{b})$ and subsequently by immunohistochemestry in the State of Rio Grande do Sul (LORETTI; BARROS, 2005). Morphologically, intraerythrocytic forms of $R$. vitalii closely resemble $B$. vogeli. Piroplasms are often scarce in the bloodstream, but might be more frequent in the acute phase of infection (CARINI; MACIEL, 1914; CARINI, 1948; LORETTI; BARROS, 2005; DA SILVA et al., 2011). The present study demonstrated that $6.8 \%$ of the samples were positive by PCR, whereas $3.9 \%$ were positive by morphological examination. Thus, PCR can be considered to be a more sensitive assay.

The sequence analysis of the six samples in our study shows that they were genetically similar to $R$. vitalii from Santa Maria (SOARES et al., 2011). The phylogenetic tree demonstrated that the six $R$. vitalii samples from this study and the $R$. vitalii from Santa Maria form a new branch of piroplasms, a conclusion that is supported by the high bootstrap value.

In summary, PCR-RFLP and sequencing revealed the presence of $R$. vitalli in Rio de Janeiro, which suggests that the geographic distribution of this parasite in Brazil is probably larger than currently known.

\section{Acknowledgements}

We would like to thank the Coordenação de Aperfeiçoamento de Pessoal de Nível Superior (CAPES), Fundação Carlos Chagas Filho de Amparo à Pesquisa do Estado do Rio de Janeiro (FAPERJ) and Conselho Nacional de Desenvolvimento Científico e Tecnológico (CNPq) for the financial support for this study. We would also like to thank Hugo Rezende for encouraging the molecular characterization of the Rangelia vitalii.

\section{References}

Birkenheuer AJ, Neel J, Ruslander D, Levy MG, Breitschwerdt EB. Detection and molecular characterization of a novel large Babesia species in a dog. Vet Parasitol2004; 124(3-4): 151-160. PMid:15381295. http:// dx.doi.org/10.1016/j.vetpar.2004.07.008

Braga A. Contribuição ao estudo experimental das piroplasmoses dos cães. Bol Vet Exército 1935; 3:1-16.

Carini A, Maciel J. Sobre a moléstia dos cães, chamada nambiuvú, e o seu parasita (Rangelia vitalli). An Paul Med Cir 1914; 3: 65-71.

Carini A. Sobre o ciclo de desenvolvimento exo-eritrocitário de um piroplasma do cão. Arq Biol 1948; 285: 49-52.

Carret C, Walas F, Carcy B, Grande N, Précigout E, Moubri K, et al. Babesia canis canis, Babesia canis vogeli, Babesia canis rossi: differentiation of the three subspecies by a Restriction Fragment Length Polymorphism analysis on amplified small subunit ribosomal RNA genes. J Eukaryot Microbiol 1999; 46(3): 298-303. PMid:10377990. http://dx.doi. org/10.1111/j.1550-7408.1999.tb05128.x

Conrad P, Thomford J, Yamane I, Whiting J, Bosma L, Uno T, et al. Hemolytic anemia caused by Babesia gibsoni infection in dogs. J Am Vet Med Assoc 1991; 199(5): 601-605. PMid:1787120.

Criado A, Martinez J, Buling A, Barba JC, Merino S, Jefferies R, et al. New data on epizootiology and genetics of piroplasms based on sequences of small ribosomal subunit and cytochrome b genes. Vet Parasitol 2006; 142(3-4): 238-247. PMid:16919391. http://dx.doi. org/10.1016/j.vetpar.2006.07.004

Criado-Fornelio A, Martinez-Marcos A, Buling-Saraña A, BarbaCarretro, A. Molecular studies on Babesia, Theileria and Hepatozoon in Southern Europe: Part I. Epizootiological aspects. Vet Parasitol 2003; 113(3-4): 189-201. http://dx.doi.org/10.1016/S0304-4017(03)00078-5

Da Silva AS, França RT, Costa MM, Paim CB, Paim FC, Dornelles GL, et al. Experimental infection with Rangelia vitalii in dogs: acute phase, parasitemia, biological cycle, clinical-pathological aspects and treatment. Exp Parasitol 2011; 128(4): 347-352. PMid:21570966. http:// dx.doi.org/10.1016/j.exppara.2011.04.010

Duh D, Tozon N, Petrovec M, Strasek K, Avsic-Zupanc T. Canine babesiosis in Slovenia: molecular evidence of Babesia canis canis and Babesia canis vogeli. Vet Res 2004; 35: 363-368. PMid:15210084. http:// dx.doi.org/10.1051/vetres:2004018

Földvári G, Hell E, Farkas R. Babesia canis canis in dogs from Hungary: detection by PCR and sequencing. Vet Parasitol 2005; 127(3-4): 221-226. PMid:15710522. http://dx.doi.org/10.1016/j.vetpar.2004.10.016

Kjemtrup AM, Conrad PA. A review of the small canine piroplasms from California: Babesia conradae in the literature. Vet Parasitol 2006; 138(1-2): 112-117. PMid:16522352. http://dx.doi. org/10.1016/j.vetpar.2006.01.045

Kjemtrup AM, Wainwright K, Miller M, Penzhorn BL, Carreno RA. Babesia conradae, sp. Nov., a small canine Babesia identified in California. Vet Parasitol 2006; 138(1-2): 103-111. PMid:16524663. http://dx.doi. org/10.1016/j.vetpar.2006.01.044

Lehtinen LE, Birkenheuer AJ, Droleskey RE, Holman PJ. In vitro cultivation of a newly recognized Babesia sp. in dogs in North Carolina. Vet Parasitol 2008; 151(2-4): 150-157. PMid:18083310. http://dx.doi. org/10.1016/j.vetpar.2007.10.022

Levine ND. Protozoan parasites of domestic animals and man. 2nd ed. Burgess Publishing; 1973. 317 p.

Loretti AP, Barros SS. Parasitismo por Rangelia vitalii em cães ("nambiuvú" "peste de sangue") - Uma revisão crítica sobre o assunto. Arq Inst Biol São Paulo 2004; 71(1):101-131.

Loretti AP, Barros SS. Hemorrhagic disease in dogs infected with an unclassified intraendothelial piroplasm in southern Brazil. Vet Parasitol 2005; 134(3-4): 193-213. PMid:16153781. http://dx.doi. org/10.1016/j.vetpar.2005.07.011

Matjila TP, Penzhorn BL, Bekker CPJ, Nijhof AM, Jongejan F. Confirmation of occurrence of Babesia canis vogeli in domestic dogs in South Africa. Vet Parasitol 2004; 122(2): 119-125. PMid:15177716. http://dx.doi.org/10.1016/j.vetpar.2004.03.019

Matjila PT, Leisewitz AL, Ooshuizen MC, Jongejan F, Penzhorn B. Detection of a Theileria species in dogs in South Africa. Vet Parasitol 2008; 157(1-2): 34-40. PMid:18687528. http://dx.doi. org/10.1016/j.vetpar.2008.06.025 
Passos LMF, Geiger SM, Ribeiro MFB, Pfister K, Zahler-Rinder M. First molecular detection of Babesia vogeli in dogs from Brazil. Vet Parasitol 2005; 127(1): 81-85. PMid:15619377. http://dx.doi. org/10.1016/j.vetpar.2004.07.028

Pestana BR. O Nambyuvú (nota preliminar). Rev Soc Cie São Paulo 1910a; 5: 14-17.

Pestana BR. O Nambyuvú. Rev Méd São Paulo 1910b; 22: 423-426.

Sá AG, Cerqueira AMF, O’Dwyer LH, Macieira DB, Abreu FS, Ferreira $\mathrm{RF}$, et al. Detection and molecular characterization of Babesia canis vogeli from naturally infected Brazilian dogs. Intern J Appl Res Vet Med 2006; 4(2): 163-168.

Soares JF, Girotto A, Brandão PE, Da Silva AS, França RT, Lopes STA, et al. Detection and molecular characterization of a canine piroplasm from Brazil. Vet Parasitol 2011; 180(3-4): 203-208. PMid:21489694. http://dx.doi.org/10.1016/j.vetpar.2011.03.024

Solano-Gallego L, Trotta M, Carli E, Carcy B, Caldin M, Furlanello T. Babesia canis canis and Babesia canis vogeli clinicopathological findings and DNA detection by means of PCR-RFLP in blood from Italian dogs suspected of tick-borne disease. Vet Parasitol 2008; 157(3-4): 211-221. PMid:18789581. http://dx.doi.org/10.1016/j.vetpar.2008.07.024

Tamura K, Peterson D, Peterson N, Stecher G, Nei M, Kumar S. MEGA 5: Molecular Evolutionary Genetics Analysis using Maximum Likelihood, Evolutionary Distance, and Maximum Parsimony Methods. Mol Biol Evol2011; 28(10): 2731-2739. PMid:21546353. http://dx.doi. org/10.1093/molbev/msr121

Trapp SM, Messick JB, Vidotto O, Jojima FS, Morais HSA. Babesia gibsoni genotype Asia in dogs from Brazil. Vet Parasitol 2006; 141(1-2): 177-180. PMid:16765518. http://dx.doi.org/10.1016/j.vetpar.2006.04.036

Uilenberg G. Babesia - A historical overview. Vet Parasitol 2006; 138(1-2): 3-10. PMid:16513280. http://dx.doi.org/10.1016/j.vetpar.2006.01.035

Zahler M, Rinder H, Schein E, Gothe, R. Detection of a new pathogenic Babesia microti-like species in dogs. Vet Parasitol 2000; 89(3): 241-248. http://dx.doi.org/10.1016/S0304-4017(00)00202-8 